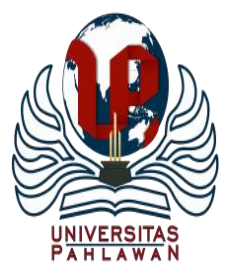

Edukatif : Jurnal Ilmu Pendidikan Volume 3 Nomor 5 Tahun 2021 Halm 2200 - 2205

EDUKATIF: JURNAL ILMU PENDIDIKAN

Research \& Learning in Education

https://edukatif.org/index.php/edukatif/index

\title{
Konsistensi Kebijakan Pendidikan di Indonesia
}

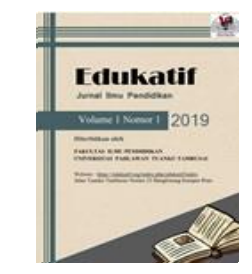

\author{
Ulil Amri ${ }^{1 凶}$, Rifma $^{2}$, Syahril $^{3}$ \\ Universitas Negeri Padang, Indonesia ${ }^{1,2,3}$
}

E-mail : ulilamri845@gmail.com ${ }^{1}, \underline{\text { rifmar34@fip.unp.ac.id }}^{2}, \underline{\text { syahril@ fip.unp.ac.id }}^{3}$

\begin{abstract}
Abstrak
Konsistensi suatu kebijakan akan memiliki pengaruh yang signifikan dalam suatu suatu proses managemen. Begitupula dengan konsistensi kebijakan pendidikan yang dikeluarkan oleh pemeritah. Karena kebijakan yang selalu berubah-rubah tentu saja akan memberikan preseden buruk terhadap proses pendidikan itu sendiri. Namun demikian dalam sejarah perjalan pendidikan di Indonesia kebijakannya sering berubah-burah, bahkan di era pendemi ini sajapun sering terjadi perubahan.Maka dalam hal ini yang mendasari penulis untuk melakukan riset mini tentang konsistensi kebijakan pendidikan di Indonesia dan pengaruhnya dengan mutu pendidikan. Metode penelitian yang dipergunakan adalah metode kepustakaan (library research) dengan menggali berbagai penelitian yang relevan baik dari buku-buku maupun jurnal-jurnal. Hasil penelitian ini adalah kebjikan pendidikan di Indonesia dari masa kemasa terus mengalami perubahan jika dimasa orde ditekankan suatu kebijakan pendidikan yang merujuk kepada isu nasionalisasi dan ideologisasi. Filosofi pendidikan diwajibkan berdasarkan Pancasila dan Manipol (Manipesto politik) UUD1945 yang materinya berorientasi pada sosialisme dalam perspektif Indonesia, kemudian pada orde baru kebijakan sentralistik, pada masa reformasi bersifat reformatif dan revolusioner.
\end{abstract}

Kata Kunci: Konsitensi, Kebijakan, Pendidikan.

\begin{abstract}
The consistency of a policy will have a significant influence in a management process. Likewise with the consistency of education policies issued by the government. Because policies that are always changing will of course set a bad precedent for the education process itself. However, in the history of the journey of education in Indonesia, the policy has often changed, even in this pandemic era, changes often occur. So in this case what underlies the author to conduct a mini research on the consistency of education policy in Indonesia and its influence on the quality of education. used is the library research method by digging up various relevant studies from books and journals. The results of this research are education policies in Indonesia from time to time continue to experience changes if during the Order era an educational policy was emphasized that refers to the issue of nationalization. and ideological. The philosophy of education is required based on Pancasila and the Manipol (Political Manipesto) of the 1945 Constitution whose material is socialism-oriented in an Indonesian perspective, then on the new order of centralized policies, during the reformation period it was reformative and revolutionary.
\end{abstract}

Keywords: Consistency, Policy, Education.

Copyright (c) 2021 Ulil Amri, Rifma, Syahril

$\triangle$ Corresponding author

Email : ulilamri845@gmail.com

DOI : https://doi.org/10.31004/edukatif.v3i5.778

ISSN 2656-8063 (Media Cetak)

ISSN 2656-8071 (Media Online)

Edukatif : Jurnal Ilmu Pendidikan Vol 3 No 5 Tahun 2021 p-ISSN 2656-8063 e-ISSN 2656-8071 


\section{PENDAHULUAN}

Pendidikan dipandang sebagai penyumbang yang sangat besar terhadap kemajuan suatu bangsa, serta merupakan wahana dalam menerjemahkan pesan-pesan konstitusi serta kesadaran dalam membangun watak bangsa (Nation Character Building). Kecerdasan yang dimiliki oleh masyarakat tentu saja akan memberikan nuasa yang cerdas pula yang secara progresif akan membentuk kemandirian. Dalam membentuk kualitas pendidikan yang dapat mengantarkan masyarakat yang cerdas dan mandiri tersebut maka dibutuhkan suatu kerangka sistem dalam penyelenggaran pendidikan yang dituangkan dalam suatu kebijakan yang ditetapkan.

Potret pembangunan pendidikan di Indonesia saat ini dapat dikatakan belum menggembirakan. Hal terebut disebabkan oleh adanya problem dalam kebijakan pendidikan tersebut, terutama pada tiga persoalan mendasar yaitu pertama pola perumusannya yang masih berpusat pada elite kekuasan, kedua banyaknya rumusan kebijakan pendidikan yang dirancang secara rumit dan mahal serta ketiga berbagai paket kebijakan tentang inovasi pendidikan hampir selalu dilakukan dengan serba cepat (instan) dan kurang mempertimbangkan berbagai implikasi secara matang (A.Rusdiana 2015). Di samping itu berbagai permasalahan klasik juga masih membelenggu sistem pendidikan diindonesia seperti menyangkut masalah kualitas, kuantitas, pemerataan, serta manajemen(Purwanto 2008).

Sistem sentralisasi pendidikan yang sebelumnya mewarnai dunia pendidikan Indonesia dengan segala plus minusnya, telah terbukti kurang efektif mengantarkan bangsa ini untuk cepat keluar dari keterpurukan. Hal ini dikarenakan kebijakan pendidikan hanya dapat menguntungkan beberapa pihak dan merugikan pihak yang lain. Di antara kelemahan sistem pendidikan selama ini adalah adanya opini yang sama bahwa pendidikan dianggap berhasil bila ia mampu menjadikan peserta didik seperti orang lain (misalnya guru, atau tokoh-tokoh yang dianggap berhasil). Nilai kemandirian dan independensi peserta didik tidak mendapatkan perhatian (Thoha Muhammad 2003).

Pendidikan yang diselenggarakan di Indonesia dipengaruhi berbagai faktor, salah satunya terkait kebijakan politik pemerintahan. Kebijakan merupakan pertimbangan akal, tentunya suatu kebijakan bukan semata-mata merupakan hasil pertimbangan akal manusia. Namun demikian akal manusia merupakan unsur manusia yang dominan di dalam mengambil keputusan dari berbagai opsi dalam pengambilan keputusan kebijakan dan kebijaksanaan yaitu lebih menekankan pada faktor-faktor emosional dan erasional bukan berarti suatu kebijaksanaan itu tidak mengandung unsur-unsur rasional (di antara sistem kehidupan tersebut tersusunlah sistem pendidikan yang diinginkan oleh bangsa Indonesia bagi seluruh rakyatnya (Kurnia 2021).

Maka berdasarkan uraian diatas, penulis tertarik melakukan suatu kajian ilmiah, dalam sebuah riset mini tentang kebijakan pendidikan di Indonesia dengan judul konsistensi kebijakan pendidikan di Indonesia.

\section{METODE PENELITIAN}

Penelitian ini berbentuk penelitan kepustakaan (library research), yaitu serangkaian penelitian yang berkenaan dengan metode pengumpulan data pustaka, atau penelitian yang objek penelitiannya digali melalui beragam informasi kepustakaan (buku, ensiklopedi, jurnal ilmiah, koran, majalah, dan dokumen) (Hadi 2000). Kajian pustaka ini dilakukan penulis dengan mengkaji tulisan ilmiah seperti buku, artikel dan jurnal. Jumlah literatur yang dipakai sebagai bahan acuan penulis dalam kajian ini yang berkaitan dengan kebijakan pemerintah terhadap pendidikan Indonesia. Kemudian penulis mengidentifikasi titik temu dari data-data primer dan sekunder yang diperoleh mengenai kebijakan-kebijakan tersebut. Adapun harapan adanya kajian ini dapat memotivasi setiap individu dalam memajukan pendidikan di indonesia menjadi lebih baik. Metode ini dipilih penulis karena efektif untuk mengkaji dan menganalisis mengenai kebijakan pemerintah terhadap pendidikan di Indonesia, karena kajian ini dianalisis penulis setiap kejadian. 


\section{HASIL DAN PEMBAHASAN PENELITIAN}

\section{Pengertian Kebijakan Pendidikan}

Kebijakan memiliki arti mengurus masalah atau kepentingan umum atau berarti juga administrasi pemerintah (Hasbullah 2015). Istilah kebijakan adalah suatu yang didasari oleh pertimbangan akal dalam proses perbuatanya (Nugroho 2009). Kebijakan juga dipahami sebagai kepandaian, kemaharian, kebijaksanaan, rangkaian konsep dan asas yang menjadi dasar dan dasar rencana dalam pelaksanaan pekerjaan, kepemimpinan, dan cara bertindak oleh pemerintah, organisasi dan sebagainya sebagai sebuah pernyataan cita-cita, prinsip ataupun maksud dari garis pedoman untuk menajemen dalam usaha mencapai sasaran (Sagala 2008).

Kemudian pendapat Hogwood dan Gun yang dikutip oleh Nanang Fatah membedakan kebijakan sebagai label untuk bidang kegiatan. Kebijakan sebagai suatu ekspresi umum dari tujuan umum atau keadaan yang diinginkan. Kebijakan merupakan proposal khusus, kebijakan sebagai keputusan pemeritah, kebijakan sebagai otorisasi formal, dan kebijakan sebagai program (Fatah 2013).

Kebijakan dalam konteks ini adalah kebijakan yang terkait dengan masalah pendidikan. Pendidikan merupakan proses tanpa akhir yang diupayakan oleh siapa pun, terutama negara. Pendidikan sebagai upaya untuk meningkatkan kesadaran dan ilmu pengetahuan. Dilihat dari makna sempitnya, pendidikan identik dengan sekolah. Kebijakan pendidikan merupakan suatu yang sifatnya esensif dan komprehensif. Kebijakan yang dibuat ditujukan untuk mengatasi suatu permasalahan yang sifatnya pelik. Kebijakan yang baik adalah kebijakan yang dibuat berdasarkan aspirasi dan berpihak kepada masyarakat dan realitas yang ada, menyahuti berbagai kepentingan dan meminimalkan adanya kerugian pihakpihak tertentu. Demikian pula halnya dengan kebijakan pendidikan, hendaknya harus mempertimbangkan banyak hal, karena menyangkut kepentingan publik yang dampaknya sangat besar.

\section{Regulasi Kebijakan Pendidikan di Indonesia dari Pasca Kemerdekaan sampai Pandemi}

Kebijakan pendidikan nasional Indonesia sesungguhnya menempati posisi yang sentral bagi usaha memajukan bangsa Indonesia. Apabila pemerintah Indonesia gagal membuat kebijakan yang unggul dalam bidang pendidikan, maka taruhannya adalah kerusakan dan kehancuran kehidupan bangsa Indonesia. Kebijakan pendidikan yang buruk akan berdampak panjang. Indonesia hanya bisa menjadi bangsa yang unggul jika kebijakan yang dihasilkan adalah kebijakan-kebijakan yang unggul dan tentu saja dapat diimplementasikan (Hubarat 2017).

Dalam sejarah perjalanan pendidikan diIndonesia pasca kemerdekaan sampai pada awal tahun 1950 tujuan pendidikan belum dirumuskan dalam suatu undang-undang yang mengatur pendidikan. Tujuan pendidikan hanya digariskan oleh Kementerian Pendidikan Pengajaran dan Kebudayaan dalam bentuk keputusan Menteri, 1 Maret 1946, yaitu warga negara sejati yang menyumbangkan tenaga dan pikiran untuk negara. Sedangkan dasar pendidikan adalah pancasila, seperti yang terumuskan dalam UUD 1945. Baru pada tahun 1950 tepatnya pada tanggal 5 April diundangkan undang-undang Nomor 4 tahun 1950 mengenai Dasardasar Pendidikan dan Pengajaran di Sekolah oleh Presiden Republik Indonesia (Mr. Asaat) dan Menteri Pendidikan, Pengajaran dan Kebudayaan (Sarmidi Mangunsarkoro), (Chairunisa 2018).

Kebijakan Sarmidi saat menjadi Menteri Pendidikan Pengajaran tidak hanya meresmikan UndangUndang Nomor 4 tahun 1950 akan tetapi Sarmidi juga mengeluarkan Putusan Menteri Pendidikan, Pengajaran dan Kebudyaan No. 120/A Tahun 1949 tentang Pemberantasan Buta Huruf (PBH) dan Peraturan Pemerintah nomer 37 tahun 1950 tentang Universitas Gajah Mada yang isiya mengenai "Statuta Universitas Gajah Mada serta masih banyak kebijakan lainnya (Chairunisa 2018).

Adapun kurikulum sekolah pada masa-masa awal kemerdekaan pada tahun 1950-an ditujukan untuk meningkatkan kesadaran bernegara dan bermasyarakat, meningkatkan pendidikan jasmani, meningkatkan pendidikan watak, memberikan perhatian terhadap kesenian, dan lain sebagainya. Menyusul meletusnya peristiwa Gestapu yang gagal, maka melalui TAP MPRS No. XXVII/MPRS/1966 tentang Agama, 
Pendidikan, dan Kebudayaan diadakan perubahan dalam rumusan tujuan pendidikan nasional yaitu "membentuk manusia Pancasilais sejati berdasarkan ketentuan-ketentuan seperti yang dikehendaki oleh pembukaan UUD 1945”.(B. Muhaemin. 2017).

Memasuki orde baru, kebijakan pendidikan di Indonesia pun mengalami berbagai perubahan diantaranya adalah pertama, melanjutkan program pemberantasan buta huruf yang pada tahun 1972 dikembangkan lebih lanjut dengan memberikan keterampilan tertentu; kedua, melaksanakan pendidikan masyarakat agat memiliki kemampuan mental, spiritual, serta keterampilan; ketiga, mengenalkan pendidikan luar sekolah yang berorientasi kepada hal-hal penting yang berkaitan dengan kehidupan sosial, ekonomi dan budaya sebagai kebutuhan praktis; keempat, mengenalkan kegiatan inovasi pendidikan, misalnya Kuliah Kerja Nyata (KKN), dibukanya sekolah dan universitas terbuka, wajib belajar, dan sebagainya; kelima, pembinaan generasi muda melalui Organisasi Siswa Intra Sekolah (OSIS), Organisasi Mahasiswa Kampus, Komite Nasional Pemuda Indonesia (KNPI), atau organisasi kepemudaan lainnya; keenam, dilaksanakannya program orang tua asuh mulai tahun 1984(Muzammil 2016). Sistem sentralistik menjadi kebijakan pendidikan utama dalam Pemerintahan Orde Baru. Politik pendidikan yang bersifat sentralistik akan memudahkan pemerintah untuk memonitor dan mengontrol jalannya penyelenggaraan pendidikan. Karena pemerintahan orde baru menyadari bahwa pendidikan adalah sarana yang paling strategis dalam meningkatkan pemberdayaan masyarakat di berbagai bidang. Agar pemeberdayaan masyarakat melalui pendidikan mengarah pada sasaran dan tujuan menurut pemerintah, maka segala perencanaan pendidikan harus ditentukan dan dikontrol oleh pusat (Muzammil 2016).

Sebagai sebuah kesimpulan bahwa Kebijakan pendidikan pada masa orde baru diarahkan pada penyeragaman. Pada masa ini tidak ada tempat bagi perbedaan pendapat, sehingga melahirkan disiplin semu dan melahirkan masyarakat peniru. Pada masa ini pertumbuhan ekonomi yang dijadikan panglima. Relevansi pendidikan diperhatikan dengan penyesuaian isi pendidikan dengan kebutuhan pembangunan terhadap sumber daya manusia yang diperlukan. Kebijakan ini secara eksplisit muncul pada pelita I, II, III, IV dan V (Hartono 2016).

Era reformasi memberi ruang yang cukup besar bagi perumusan kebijakan pendidikan baru yang bersifat reformatif dan revolusioner. Pendidikan di era reformasi 1999 mengubah wajah sistem pendidikan Indonesia melalui UU No 22 tahun 1999, dengan ini pendidikan menjadi sektor pembangunan yang didesentralisasikan. Pemerintah memperkenalkan model "Manajemen Berbasis Sekolah". Sementara untuk mengimbangi kebutuhan akan sumber daya manusia yang berkualitas, maka dibuat sistem "Kurikulum Berbasis Kompetensi”. Memasuki tahun 2003 pemerintah membuat UU No.20 tahun 2003 tentang sistem pendidikan nasional menggantikan UU No 2 tahun 1989, dan sejak saat itu pendidikan dipahami sebagai, "Usaha sadar dan terencana untuk mewujudkan suasana belajar dan proses pembelajaran agar peserta didik secara aktif mengembangkan potensi dirinya untuk memiliki kekuatan spiritual keagamaan, pengendalian diri, kepribadian, kecerdasan, akhlak mulia, serta keterampilan yang diperlukan dirinya, masyarakat, bangsa dan Negara (Standar Pendidikan Nasional 2005).

Anggaran pendidikan ditetapkan sesuai dengan UUD 1945 yaitu 20\% dari APBN dan APBD, sehingga banyak terjadi reformasi di dunia pendidikan, terutama dalam dalam pemberian dana Bantuan Operasional Sekolah (BOS), Wajib Belajar 9 tahun, dan peningkatan standar penghasilan guru dengan adanya sertifikasi guru, serta pemberian bantuan pendidikan (Beasiswa) untuk peningkatan kompetensi guru, dan sebagainya. Pasal 39 Ayat (2) Undang-Undang Nomor 20 tahun 2003 tentang sistem pendidikan nasional bahwa pendidik merupakan tenaga profesional. Kedudukan guru dan dosen sebagai tenaga profesional mempunyai visi terwujudnya penyelenggaraan pembelajaran sesuai dengan prinsip-prinsip profesionalitas untuk memenuhi hak yang sama bagi setiap warga negara dalam memperoleh pendidikan yang bermutu.

Undang-undang nomor 14 tahun 2005 tentang guru dan dosen pasal 2 ayat (1) guru sebagai tenaga profesional mengandung arti bahwa pekerjaan guru hanya dapat dilakukan oleh seseorang yang memiliki kualifikasi akademik, kompetensi, dan sertifikat pendidik sesuai dengan persyaratan untuk setiap jenis dan 
jenjang pendidikan tertentu. Pasal (4) Yang dimaksud dengan guru sebagai agen pembelajaran (learning agent) adalah peran guru antara lain sebagai fasilitator, motivator, pemacu, perekayasa pembelajaran, dan pemberi inspirasi belajar bagi peserta didik.(Hartono 2016).

Masa pandemi merupakan kondisi dimana kejadian wabah penyakit sudah menyebar secara global. Menurut WHO (World Health Organisation) sesuatu itu dikatakan pandemi manakala terjadinya penyakit sudah menyebar keseluruh dunia melampaui batas. Penyebaran virus corona yang sangat massif telah mengakibatkan aktivitas manusia menjadi serba di rumahkan. Bertatap muka langsung dalam setiap kegiatan pembelajaran menjadi pembelajaran yang dilangsungkan di rumah (BDR) karena untuk menghindari paparan penularan virus yang semakin massif dari waktu ke waktu. Proses kegiatan belajar mengajar harus tetap berjalan dan peserta didik jangan kehilangan haknya dalam belajar.

Sekolah sebagai lembaga penyelenggara pendidikan harus cepat tanggap terhadap fenomena wabah covid 19 dengan senantiasa berupaya agar proses pembelajaran dapat terlaksana secara efektif. Pemerintah dalam hal ini menteri pendidikan telah menetapkan kebijakan pendidikan di tengah pandemi dengan mengeluarkan surat edaran Nomor 15 tahun 2020 tentang pedoman penyelenggaraan belajar dari rumah (BDR) dalam masa darurat penyebaran Corona Virus Desease (Covid 19). Dalam rangka pemenuhan hak peserta didik untuk mendapatkan layanan pendidikan selama darurat penyebaran virus corona, maka penyelenggaran pendidikan dilakukan melalui program pembelajaran jarak jauh (PJJ). Metode pembelajaran yang dikembangkan selama proses pembelajaran jarak jauh dapat dilakukan dengan menggunakan metode pembelajaran daring dan luring (Barimi et al. 2013).

\section{KESIMPULAN}

Kebijakan dan penyelenggaraan pendidikan tak mungkin lepas dari kondisi politik. Pendidikan sering dijadikan alat untuk mengiring masyarakat mengarah pada tujuan politik yang diinginkan oleh negara. Penyelenggaraan pendidikan di tanah air yang berlandaskan Pancasila pada masa orde lama di mulai sejak dikumandangkannya proklamasi kemerdekaan. Indonesia pada masa orde lama merupakan negara yang sarat akan cita-cita sosialisme, sehingga kebijakan pendidikan pada masa orde lama juga harus selaras yaitu pendidikan sosialisme. Politik dan pendidikan di Indonesia terlihat sedemikian erat. Kegiatan-kegiatan kependidikan sudah banyak dipengaruhi oleh para penguasa dengan tujuan untuk mempertahankan kekuasaan mereka. Kebijakan pendidikan sudah menjadi tema kompetisi antar partai politik, pada setiap pentas pemilu. Pendidikan lebih merupakan alat untuk mana pemerintah menggunakannya untuk mengiring rakyat dan umat kepada tujuan politik yang diinginkan secara teoritis tidaklah salah jika pemerintah menginginkan agar produk lulusan lembaga pendidikan memberikan konstribusi bagi pembangunan. Namun pada saat yang sama seharusnya pemerintah juga memberikan kebebasan kepada dunia pendidikan untuk menentukan arahnya dengan tetap memperoleh bantuan, dukungan dan fasilitas dari pemerintah.

\section{UCAPAN TERIMA KASIH}

Penulis mengucapkan terima kasih pada pihak yang telah membantu suksesnya penelitian ini, terutama Ibu Dr.Rifma, M.Pd, dan Bapak DrsSyahril, M.Pd,Phd selaku dosen pembimbing sehingga selesai makalah ini.

\section{DAFTAR PUSTAKA}

A.Rusdiana. 2015. Kebijakan Pendidikan Dari Filosofi Ke Implementasi. Bandung: Pustaka Setia.

B, Muhaemin. 2017. "Kebijakan Pengembangan Pendidikan.” AL-ISHLAH: Jurnal Pendidikan Islam 15(1): $1-14$. 
2205 Konsistensi Kebijakan Pendidikan di Indonesia - Ulil Amri, Rifma, Syahril DOI: https://doi.org/10.31004/edukatif.v3i5.778

Barrimi, M. Et Al. 2013. "Kebijakan Pendidikan Di Masa Pandemi." Encephale 53(1): 59-65. Http://Dx.Doi.Org/10.1016/J.Encep.2012.03.001.

Chairunisa, Chairunisa. 2018. "Kebijakan Pendidikan Di Indonesia Pada Masa Menteri Sarmidi Mangunsarkoro (1949-1950)." Risalah $\quad$ 5(6): Http://Journal.Student.Uny.Ac.Id/Ojs/Index.Php/Risalah/Article/View/12755.

Fatah, Nanang. 2013. Analisis Kebijakan Pendidikan. Bandung: Remaja Rosdakarya.

Hadi, Sutrisno. 2000. Metodologi Reserach. Yogyakarta: Rake Sari.

Hartono, Yudi. 2016. "Pendidikan Dan Kebijakan Politik (Kajian Reformasi Pendidikan Di Indonesia Masa Orde Lama Hingga Reformasi).” Jurnal Agastya Vol 6 No 1.

Hasbullah, M. 2015. Kebijakan Pendidikan (Dalam Perspektif Teori, Aplikasi, Dan Kondisi Objektif Pendidikan Di Indonesia). Jakarta: Rajawali Press.

Hubarat, Binsar A. 2017. "Kebijakan Pendidikan Di Indonesia: Evaluasi Terhadap Rumusan Kebijakan Kurikulum Bidang Pendidikan Tinggi Binsar A . Hutabarat.” Societas Dei 4(2): 127-46.

Kurnia, Hawa. 2021. "Edukatif: Jurnal Ilmu Pendidikan Kebijakan Pemerintah Terhadap Kondisi Pendidikan Di Indonesia Pada Masa Orde Lama." 3(3): 839-46.

Muzammil, As'ad. 2016. "Kebijakan Pemerintah Dalam Bidag Pendidikan Dari Orde Lama Sampai Orde Baru.” Jurnal Kependidikan Islam 2(2): 183-98.

Nugroho, H.A.R Tilaar Dan Riant. 2009. Kebijakan Pendidikan: Pengantar Untuk Memahami Kebijakan Pendidikan Dan Kebijakan Pendidikan Sebagai Kebijakan Publik. Yogyakarta: Pustaka Pelajar.

Purwanto, N. 2008. "Perjalanan Kebijakan Pendidikan Di Indonesia." Jurnal Manajemen Pendidikan 8(2).

Sagala, Syaiful. 2008. Administrasi Pendidikan Kontemporer. Bandung: Alfabeta.

“Standar Pendidikan Nasional.” 2005.

Thoha Muhammad. 2003. "Perkembangan Kebijakan Pendidikan (Studi Tentang Implementasi Manajemen Berbasis Sekolah).” Jurnal Tadris Kebijakan Pendidikan Volume II(Nomor 1): 109-19. 